\title{
DEVIDO PROCESSO PENAL E ALGUNS DOS SEUS MAIS IMPORTANTES COROLÁRIOS
}

\author{
Rogério Lauria Tucci \\ Professor Titular do Departamento de Direito Processual \\ da Faculdade de Direito da Universidade de São Paulo
}

\begin{abstract}
Resumo:
Partindo da determinação conceptual do devido processo penal, à luz das normas constitucionais, são especificados alguns de seus mais importantes corolários.

Assim sendo, a assecuração do devido processo penal decorre das garantias da "presunção de inocência" e prisão provisória; da contraditoriedade no inquérito policial; da imprescindibilidade de autorização judicial para a busca e apreensão; e, de idêntico modo, para a interceptação das comunicações telefônicas.
\end{abstract}

Abstract:

Starting from a concept of the due criminal process, according to constitutional rules, some of its most important principles are taken under special consideration.

Therefore, the assurance of the due criminal process is related to the guaranties of the "presumption of innocence" and provisory imprisonment; the right of hearing during the preliminary investigation; the indispensability of judicial warrant for search and seisure, and for interceptions of private telephone calls.

\section{Sumário:}

\section{$\S 1^{\circ}$ - DETERMINAÇÃO CONCEPTUAL DO DEVIDO PROCESSO PENAL:}

1. Preceituações constitucionais e Direito Processual Penal.

2. Garantia de tutela jurisdicional.

3. Devido processo legal.

4. Devido processo penal.

$\S 2^{\circ}$ - ESPECIFICAÇÃO DE ALGUNS DOS MAIS RELEVANTES DIREITOS E GARANTIAS ÍNSTTAS AO DEVIDO PROCESSO PENAL:

5. "Presunção de inocência" e prisão provisória.

6. Contraditoriedade no inquérito policial.

7. Imprescindibilidade de autorização judicial para a busca e apreensão.

8. Interceptação de comunicações telefônicas. 


\section{$\S 1^{2}$ - DETERMINAÇÃo CONCEPTUAL dO DEVIDO PROCESSO PENAL}

\section{Preceituações constitucionais e Direito Processual Penal}

Impõem-se ao estudioso do Direito Processual Penal, preambularmente, a verificação, entre outras noções que ostentam real importância, dos regramentos constitucionais atinentes ao processo penal, tidos, generalizada e equivocamente, como "princípios constitucionais do processo penal".1

Manifesta e constante é, com efeito, a influência exercida pelos preceitos constitucionais sobre todas as demais normas componentes do ordenamento jurídico à luz deles editadas, especialmente as processuais penais, que constituem, segundo uniforme e corrente entendimento doutrinário, seu necessário complemento. ${ }^{2}$

Ademais, Lei das leis, situada no mais elevado ponto da hierarquia das formas de expressão do ius positum, e contendo os fundamentos políticos e institucionais de toda a legislação ordinária, em seus textos - como precisa José Frederico Marques, ${ }^{3}$ repousam numerosos dispositivos e institutos processuais penais.

E dado, ainda, consistir a jurisdição criminal numa atividade estatal determinada à aplicação do Direito Penal material a um conflito de interesses de alta relevância social; corresponder um destes ao anseio de liberdade do ser humano, que se faz fundamento do processo penal; e constituírem as normas processuais penais, sempre, "atualidades das garantias constitucionais", qualquer que seja o ângulo visualizado, presentam-se as preceituações constitucionais respeitantes ao Direito Processual Penal como base e diretriz das normas reguladoras do respectivo processo.

1. V., a respeito, das acepções de princípio no singular, porque único - e regras, de nossa autoria e de outros, Princípio e regras orientadoras do novo processo penal brasileiro, Rio de Janeiro, Forense, 1986, p. 27 e ss.

2. Cf., por todos, Vicente de Paulo Vicente de Azevedo, Curso de direito judiciário penal, São Paulo, Saraiva, 1958, v. 1, p. 30-1.

3. Elementos de direito processual penal, 2a. ed., Rio de Janeiro, Forense, 1965, v. 1, p. 71-2. 
2. Garantia de tutela jurisdicional

Expendidas essas sucintas e imprescindíveis considerações, bem é de ver que a atual Constituição Federal, promulgada em 05 de outubro de 1988, a exemplo das precedentes, e de modo igualmente expresso, contém várias disposições alusivas ao Direito Processual Penal, implicativas, outrossim, da orientação determinante da edição de normas disciplinadoras do processo penal.

Assim também - já agora de maneira implícita (a teor do $\S 2^{o}$ do art. $5^{\circ}$, verbis: "Os direitos e garantias expressos nesta Constituição não excluem outros decorrentes do regime e dos princípios por ela adotados, ou dos tratados internacionais em que a República Federativa do Brasil seja parte"), integrados na formação do sistema em que consubstanciado o ordenamento jurídico brasileiro - de outros, igualmente postos com a finalidade de plasmar as variegadas instituições e, correlatamente, estabelecer, completa e cientificamente, a normatividade do Direito Processual Penal.

Tais regras, na essência de Direito Processual Constitucional, firmando direitos subjetivos individuais e as correspondentes garantias, são, exatamente, os por nós denominados regramentos constitucionais do processo penal, e podem ser alinhadas a partir da concepção de Direito Processual como "expressão com conteúdo próprio, em que se traduz a garantia da tutela jurisdicional do Estado através de procedimento demarcado formalmente em lei" 4

Essa garantia de tutela jurisdicional, aliás, consiste, por sua vez, num direito público subjetivo, universalmente consagrado, e decorrente da assunção, pelo Estado, do monopólio da administração da Justiça: é conferida ao membro da comunhão social (inclusive, à evidência, ao próprio Estado), em contrapartida, o direito de invocar prestação ou providência jurisdicional, relativamente a determinado interesse, em conflito com o de outrem.

Denominada direito ao processo, ou, mais precisamente, direito à tutela jurisdicional do Estado, tem sido, definida, sucessivamente, nas mais importantes declarações de direitos humanos (Declaração Universal dos Direitos do Homem, proclamada pela Organização das Nações Unidas - ONU, 
em 10 de dezembro de 1948, art. 10; Convenção Européia para Salvaguarda dos Direitos do Homem e das Liberdades Fundamentais, subscrita no dia 04 de novembro de 1950, art. 6², n. 1; Pacto Internacional de Direitos Civis e Políticos, de 16 de dezembro de 1966, art. 14, n. 1; Convenção Americana sobre Direitos Humanos, assinada em 22 de novembro de 1969, art. 8º, n. 1); e encontra-se, na esteira das antecedentes, repristinada no art. $5^{\circ}, \mathrm{XXXV}$, da vigente Carta Magna de nossa República Federativa, a saber:

art. 59 Todos são iguais perante a lei, sem distinção de qualquer natureza, garantindo-se aos brasileiros e aos estrangeiros residentes no País a inviolabilidade do direito à vida, à liberdade, à igualdade, à segurança e à propriedade, nos termos seguintes:

XXXV a lei não excluirá da apreciação do Poder Judiciário lesão ou ameaça a direito".

Consagra-se, destarte, uma vez mais, e de maneira inarredável, um dos mais expressivos direitos subjetivos materiais conferidos pelo Estado aos integrantes da comunidade, qual seja o direito à jurisdição. ${ }^{5}$

E a tal corresponde, como precedentemente aventado, a determinação proemial, efetivada no mais alto plano da hierarquia das leis, da garantia de tutela jurisdicional a todos quantos vivam ou existam no território nacional, igualados em tudo, no tocante aos direitos ditos fundamentais e respectivas garantias.

5. Cf., de José Rogério Cruz e Tucci e nosso, Constituição de 1988 e processo. Regramentos e garantias constitucionais do processo, São Paulo, Saraiva, 1989, p. 12, em que conceituada a jurisdição como "poder-dever" concedido aos agentes do Poder Judiciário - juizes e tribunais para, no exercício de função em lei definida, e mediante atividade substitutiva da dos membros da comunhão social, realizar o direito aplicável a uma pretensão (no processo civil) ou a um conflito de interesses de alta relevância social (no campo penal)". 


\section{Devido processo legal}

Colocando-se, para os interessados, a par ou à margem do direito à jurisdição, o ônus de demandar consoante preciso magistério de Joaquim Canuto Mendes de Almeida, por nós sobrelevado na Apresentação do livro intitulado Processo penal, ação e jurisdição ${ }^{6}$ - por certo que o adimplemento deste, com a propositura da ação, origina a formaçáo do processo, que, segundo entendemos, se presenta como instrumento, técnico e público, de realização de Justiça, pelos órgãos jurisdicionais.

Isso significa, outrossim, que o processo consiste, precipuamente, numa garantia outorgada pela Lei das leis à efetivação do direito (subjetivo, material e público) à jurisdição.

E, por via de conseqüência, que, constitucionalmente assegurado a todos os integrantes da sociedade (a teor do art. 5o, LIV, da Constituição Federal: "ninguém será privado da liberdade ou de seus bens sem o devido processo legal"), se impõe sua consideração como encartado no due process of law.

Trata-se esta em vernáculo devido processo legal, e como explicitado na já referida monografia Constituição de 1988 e processo ${ }^{7}$ - de difundida locução mediante a qual se determina a imperiosidade, num proclamado Estado de Direito, de:

a) elaboração regular e correta da lei, bem como sua razoabilidade, senso de justiça e enquadramento nas preceituações constitucionais (substantive due process of law, segundo o desdobramento da concepção norte-americana);

b) aplicação judicial das normas jurídicas (não só da lei, como tal própria e estritamente concebida, mas, por igual, de toda e qualquer forma de expressão do direito), através de instrumento hábil à sua interpretação e realização, que é o processo (judicial process); e,

c) assecuração, neste, de paridade de armas entre as partes, visando à igualdade substancial.

6. São Paulo, Revista dos Tribunais, 1975.

7. p. $15-6$. 
Apresenta-se, ademais, relativamente ao processo judicial, como um conjunto de elementos indispensáveis para que este possa atingir, devidamente, sua já aventada finalidade compositiva de litígios (em âmbito extrapenal) ou resolutória de conflitos de interesses de alta relevância social (no campo penal).

E consubstancia-se, sobretudo, como igualmente visto, numa garantia conferida pela Magna Carta, objetivando a consecução dos direitos denominados fundamentais através da efetivação do direito ao processo, materializado num procedimento regularmente desenvolvido, com a imprescindível concretização de todos os seus respectivos corolários, e num prazo razoável.

\section{Devido processo penal}

Esses consectários, por sua vez, constituem na força de seu conjunto, e em sede penal, o devido processo penal - expressão apropriada (dotada de rigor técnico) à sua designação no específico campo processual de atuação, como bem explica Pedro J. Bertolino, ${ }^{8}$ concluindo, verbis: "Claro está que la denominación de 'penal' adscripta a la garantía menta, por cierto, el modo corriente con el cual se indica al derecho que en el proceso respectivo se actúa. Este es, digámoslo así, el sentido más apropiado y riguroso de la denominación".

Especificam-se, outrossim, nas garantias: a) de acesso à Justiça Penal; b) do juiz natural em matéria penal; c) de tratamento paritário dos sujeitos parciais do processo penal; d) da plenitude de defesa do indiciado, acusado ou condenado, com todos os meios e recursos a ela inerentes; e) da publicidade dos atos processuais penais; f) da motivação dos atos decisórios penais; e g) da fixação de prazo razoável de duração do processo penal.

E determinam, inequívoca e inexoravelmente, que uma pessoa física não pode ser privada de sua liberdade (ou de outros bens, a ela correlatos) sem o devido processo penal, em que se realize a ação judiciária, atrelada ao vigoroso e incindível relacionamento entre as preceituações constitucionais e as normas penais, quer de natureza substancial, quer de caráter instrumental, e de sorte a tornar efetiva a atuação da Justiça Criminal, tanto na inflição e na 
concretização da pena, ou da medida de segurança, como na afirmação do ius libertatis.

Neste derradeiro enfoque, cumpre salientar o generalizado reconhecimento de que o ser humano, membro da comunhão social, antes de sofrer qualquer sanção penal, tem direito a um processo prévio, em que garantidas: a) a atuação de órgão jurisdicional antecedentemente designado pela lei para o respectivo julgamento, independente e imparcial; b) a determinação legal de um procedimento destinado à investigação e posterior julgamento acerca de fato penalmente relevante; c) o proferimento deste, em prazo razoável, pública e motivadamente; d) a correlação entre acusação e sentença; e) a possibilitação de reexame de atos decisórios desfavoráveis ao imputado; f) a propiciação de ampla defesa, tanto material, como tecnicamente; e g) o não reconhecimento de culpabilidade, senão quando transitada em julgado a sentença condenatória. ${ }^{9}$

Ademais, o destaque propositadamente feito reclama a verificação do enunciado do $\S 2^{Q}$ do art. $5^{\varrho}$ da Constituição Federal brasileira em vigor, cuja repetida transcrição se faz necessária, verbis: "Os direitos e garantias expressos nesta Constituição não excluem outros decorrentes do regime e dos princípios por ela adotados, ou dos tratados internacionais em que a República Federativa do Brasil seja parte" (com grifos nossos).

Ora, nosso País é um dos signatários da Convenção Americana sobre Direitos Humanos, assinada em São José, Costa Rica, no dia 22 de novembro de 1969, e cujo art. $\mathbf{8}^{2}$, n. 1, tem a seguinte redação: "Toda pessoa tem direito de ser ouvida com as devidas garantias e dentro de um prazo razoável por um juiz ou tribunal competente, independente e imparcial, estabelecido por lei anterior, na defesa de qualquer acusação penal contra ela formulada, ou para determinação de seus direitos e obrigações de ordem civil, trabalhista, fiscal ou de qualquer outra natureza..." (com grifos também nossos).

$\mathrm{E}$, assim sendo, por certo que se afigura inaceitável o prolongamento do curso do processo penal além do tempo necessário à consecução de sua finalidade, qual seja a definição da relação jurídica

9. Cf., em senso assemelhado, José I. Cafferata Nores, Derechos individuales e proceso penal, Córdoba, Ediar, 1984, p. 21-5. 
estabelecida entre o cidadão envolvido na persecutio criminis e o Estado: o imputado tem, realmente, direito à pronta determinação de "sua situação ante a função penal do Estado" 10

Em suma, na concepção do devido processo penal torna-se inafastável a inclusão, também, do direito do indiciado ou acusado, de obter pronunciamento judicial que "ponha termo do modo mais rápido possível à situação de incerteza e de inegável restrição da liberdade que lhe é acarretada pela persecução penal". 11

\section{$\S 2^{\circ}$ - ESPECIFICAÇĀO DE ALGUNS DOS MAIS RELEVANTES DIREITOS E GARANTIAS ÍNSITAS AO DEVIDO PROCESSO PENAL}

5. "Presunção de inocência" e prisão provisória

Tudo isso devidamente explicitado, parece-nos oportuna a análise mais detida de alguns temas cuja importância se torna despiciendo asseverar.

É o que passamos a fazer, não sem antes relembrar as idéias liberais que nortearam a Assembléia Constituinte na elaboração do lavor legislativo que resultou na edição da Lei Maior de 1988, especialmente no tocante à elencação dos "direitos e deveres individuais e coletivos", no Capítulo I do Título II ("Dos direitos e garantias fundamentais").

Assim também, na esteira de doutrinação de Emilio Betti, ${ }^{12}$ que a interpretação reclamada pelo Direito, sobretudo a da norma constitucional, é a

10. V., a respeito, Pedro J. Bertolino, ob. cit., p. 79; José I. Cafferata Nores, Eficacia de la persecución penal y garantias procesales en la Constitución de Córdoba, Córdoba, Lemer, 1987, p. 26-7; Alejandro D. Carrió, Garantias constitucionales en el proceso penal, Buenos Aires, Hammurabi, 1984, p. 130 e ss.; Jose Antonio Tome Garcia, Protección procesal de los derechos humanos ante los tribunales ordinarios, Madrid, Montecorvo, 1987, p. 57-8 e 118-21; Vicente Gimeno Sendra, Constitución y proceso, Madrid, Tecnos, 1988, p. 137-9; Daniele Saint-Laurent, Principes de droit constitutionnel et pénal, Québec, Modulo, 1986, p. 126-7; André Morel, Cerain guarantees of criminal procedure, The Canadian Charter of Rights and Freedoms (obra coletiva), $2^{\mathrm{a}}$ ed., Toronto, Carswell, 1989, p. 497 e ss.

11. Cf., ainda, Alejandro D. Carrió, ob. cit., p. 132.

12. La interpretazione delle legge e degli atti giuridici, Milano, Giuffré, 1949, p. 3 (e que se difundiu, inclusive entre nós, e. g., Fran Figueiredo, Metodologia constitucional: técnicas de elaboração e técnicas de interpretação, Brasília, Ministério das Relações Exteriores, 1987, p. 178; 
voltada ao reconhecimento e à reconstrução do seu significado, como "forma representativa" do respectivo conteúdo, e feita "fonte de valoração jurídica, ou que constitua objeto desta valoração".

Pois bem, um dos temas que se tornaram polêmicos com o advento da vigente Constituição Federal é o relativo à denominada "presunção de inocência" e a prisão provisória.

Expressam, nesse particular, os incs. LVII e LXI do art. 50, respectivamente, que: "ninguém será considerado culpado até o trânsito em julgado de sentença penal condenatória"; e "ninguém será preso senão em flagrante delito ou por ordem escrita e fundamentada da autoridade judiciária competente, salvo nos casos de transgressão militar, ou crime propriamente militar, definidos em lei" (com todos os grifos nossos).

E traduzem, induvidosamente, duas diversificadas concepções: a da correntemente afirmada "presunção de inocência" e a da determinação e formalização da prisão provisória.

A primeira reclama a formação da coisa julgada de autoridade relativa (isto é, a correspondente ao trânsito em julgado de sentença penal condenatória, sempre sujeita à rescisão), e a outra diz com os enunciados dos arts. 301 e ss., 311 a 316, 393, I, 408, § 1º, e 594 do Código de Processo Penal; art. 35 da Lei de Tóxicos (Lei n. 6.368, de 21 de outubro de 1976), e art. $1^{9}$ e ss. da Lei n. 7.960, de 21 de dezembro de 1989.

Para bem correlacioná-las, faz-se mister verificar, de logo, quais as espécies de prisão provisória e suas respectivas características.

Com efeito, inobstante a conotação preponderantemente cautelar que todas elas ostentam, as diferentes espécies de prisão provisória (como tal conceituada a efetuada precedentemente ao proferimento da sentença condenatória, ou até que ela se torne irrecorrível) agrupam-se em duas, por força de critério distintivo firmado na sua conformação.

Se não, vejamos.

Cinco são, atualmente, em nosso processo penal comum, as mencionadas espécies de prisão provisória, sendo quatro delas previstas no

Nagib Slaibi Filho, Anotações à Constituição de 1988: aspectos fundamentais, $2^{\mathrm{a}}$ ed., Rio de Janeiro, Forense, 1989, p. 86. 
Código de Processo Penal, a saber: a) prisão em flagrante delito (art. 302, I a IV); b) prisão preventiva (arts. 311 a 316); c) prisão decorrente de ato decisório de pronúncia, nos processos referentes a crimes cujo julgamento seja da competência do Tribunal do Júri (art. 408, $\S 1^{2}$ ); e d) prisão resultante de sentença condenatória recorrível (arts. 393, I, e 594).

A outra, prisão temporária, cujos contornos se definiram, primeiramente, no Anteprojeto de Código de Processo Penal, que se converteu no Projeto ora em tramitação no Congresso Nacional n. 1.655 , de $1983,{ }^{13}$ foi instituída pela já indicada Lei n. 7.960 , de 1989, com o mesmo escopo de encarceramento provisório do indiciado no lapso temporal entre a iniciação da informatio delicti mediante portaria (inocorrente, portanto, a prisão em flagrante delito) e o momento em que verificada a possibilidade de imediata reunião dos elementos necessários à decretação da prisão preventiva.

Três delas, quais sejam, a prisão em flagrante delito, a prisão preventiva e a prisão temporária, são, na realidade, tipicamente cautelares, isto é, têm por finalidade a assecuração do resultado profícuo do processo penal de conhecimento de caráter condenatório, quer para a garantia da ordem pública, quer em razão da conveniência da instrução criminal ou para preservar a aplicação da lei penal (cf. art. 312 do apontado Código).

As outras duas, porém, tendo como pressuposto o proferimento de ato decisório de pronúncia ou de condenação, assumem natureza marcadamente processual: enquanto as tipicamente cautelares firmam-se em fatos extra e meta-processuais, elas ocorrem no âmbito de processo em curso, necessariamente vinculadas a ato processual, de que derivam.

Assim, não podem ser confundidos, de maneira alguma, os pressupostos da ordem judicial, encarceramento provisório com os de um pronunciamento interlocutório de outra índole, ou condenatório, no processo penal de conhecimento. Os daquela encontram-se estatuídos no já aludido art. 312 do Código de Processo Penal; os destes, por sua vez, dizem com a conviç̧ão do órgão jurisdicional pronunciante sobre a viabilidade da acusação,

13. V., a respeito, Sérgio Marcos de Moraes Pitombo, Prisão temporária e crise urbana, Revista dos Tribunais, São Paulo, n. 603, p. 296-7, 1986. 
encaminhando o processo a julgamento pelo Tribunal do Júri; ou com a certeza acerca da materialidade do fato criminoso e da indigitada autoria.

Por via de conseqüência, somente quando aqueles guardem estrita correlação com estes torna-se admissível o aprisionamento prévio do apontado autor da prática delituosa. E, então, sem nenhuma afronta ao transcrito inc. LVII do art. $5^{\circ}$ da Constituição Federal, até porque a prisão provisória tipicamente cautelar não implica, qualquer seja o ângulo de sua visualização, apriorística consideração de culpa do ser humano envolvido na persecutio criminis.

Como anota, a este propósito, Fernando da Costa Tourinho Filho, ${ }^{14}$ verifica-se, na realidade, em tal hipótese, a indispensabilidade de segregação imediata, face à possibilidade de perturbação da ordem pública, de criação de óbice, tumulto ou desorientação da instrução criminal ou, ainda, de frustração da aplicação da lei penal.

Já agora, todavia, a prisão provisória de natureza processual, decorrente de ato decisório de pronúncia ou de sentença condenatória recorrível, ou recorrida, não tem como se manter perante o examinado regramento constitucional, sobretudo por significar antecipada admissão de culpabilidade do pronunciado ou do condenado, de todo inadmissível.

E, dado o exposto, sobrevém a inarredável conclusão de que:

a) restam de todo ineficazes, não tendo mais como serem aplicados, desde a edição da Constituição Federal de 1988, e. g., os arts. 393, I, 408, § 1ํo, e 594 do Código de Processo Penal, e 35 da Lei n. 6.368, de 1976;

b) a nova Carta Magna de nossa República Federativa, por outro lado, permite, não só a prisão em flagrante delito, com as cautelas especificadas nos incs. XI, LXIX, LVI, LVIII, LXII, LXIII e LXVI do art. 5o, bem como a temporária e a preventiva, desde que calcadas em ordem escrita e fundamentada de órgão jurisdicional competente (cf. inc. LXI do mesmo artigo); e,

c) essa, assim sintetizada, e induvidosamente, é a única interpretação que se coaduna com o enunciado da Súmula n. 09 do Superior Tribunal de Justiça ("A exigência de prisão provisória, para apelar, não ofende a garantia constitucional da presunção de inocência"), cuja liberalidade, com o 
devido respeito, presenta-se gritantemente afrontosa do preceito constitucional focado.

Acrescente-se, por oportuno, que o texto da lei, quando claro, inadmite interpretação restritiva, extensiva ou diversificativa (vocábulo ora utilizado para referir posicionamento como o ostentado por Antônio Magalhães Gomes Filho, na monografia intitulada Presunção de inocência e prisão cautelar; ${ }^{15}$ devendo prevalecer a que revela, explicitamente, a mens legislatoris transfundida na mens legis: "En él es donde se halla expressamente establecida su intención; querer indagarla en otra parte es peligroso".16

Igualmente, com Weber Martins Batista, ${ }^{17}$ que o "status de inocência do réu ou com maior razão - do indiciado, não permite a imposição de qualquer restrição à sua liberdade, que não seja absolutamente necessária. A prisão provisória, como medida cautelar ou de segurança, não sendo uma pena antecipada, só assim se justifica"

6. Contraditoriedade no inquérito policial

Outro tema que clama pela atenção do analista é o referente à contraditoriedade no inquérito policial.

A Constituição Federal de 1988, inovando vigorosamente na matéria, deixou assentado no mesmo art. $5^{\circ}$, LV, LXII e LXIII, respectivamente, que: "aos litigantes, em processo judicial ou administrativo, e aos acusados em geral são assegurados o contraditório e ampla defesa, com os meios e recursos a ela inerentes"; "a prisão de qualquer pessoa e o local onde se encontre serão comunicados imediatamente ao juiz competente e à familia do preso ou à pessoa por ele indicada"; e "o preso será informado de seus direitos, entre os quais o de permanecer calado, sendo-lhe assegurada a assistência da família e de advogado".

Percebe-se, desde logo, sem o mínimo esforço de raciocínio, que o nosso legislador constituinte pontuou, no primeiro dos incisos transcritos, a real

15. São Paulo, Saraiva, 1991, p. 65 e ss.

16. Cf., Pascuale Fiore, De la irretroatividad e interpretación de las leyes, tr. castelh. Enrique Aguillera de Paz, $3^{\text {a }}$ ed., Madrid, 1927, p. 591.

17. Liberdade provisória, Rio de Janeiro, Forense, 1981, p. 117. 
diferença entre o conteúdo do processo civil, cuja já verificada finalidade é a compositiva de litígios, e o do processo penal, em que pessoa física, integrante da comunidade, é indiciada, acusada e, até, condenada pela prática de infração penal.

Orientou-se, aliás, nesse particular, pela mesma trilha que, na esteira dos ensinamentos de Calamandrei e Luciano Marques Leite, há anos percorremos em nossas aulas no Curso de Pós-Graduação da Faculdade de Direito da Universidade de São Paulo, e, já agora, fortalecida, não só pela lúcida preceituação constitucional em referência, como também por jovens e autorizados especialistas pátrios, e. g. Jacinto Nélson de Miranda Coutinho, na excelente monografia intitulada $\mathrm{A}$ lide e o conteúdo do processo penal; ${ }^{18} \mathrm{e}$, mais recentemente, José Carlos Teixeira Giorgis, A lide como categoria comum do processo. $^{19}$

$\mathrm{E}$, de modo também induvidoso, reafirmou os regramentos do contraditório e da ampla defesa, com todos os meios e recursos a ela inerentes, estendendo sua incidência, expressamente, aos procedimentos administrativos.

Igualmente, para que esta não configurasse uma utopia, determinou a indispensabilidade de imediata comunicação da prisão e do local onde o preso se encontre ao juiz competente e à familia, ou pessoa por ele indicada; assim como, em complemento, da informação explícita de seus direitos, especialmente no tocante ao silêncio e à assistência de advogado.

Representa o direito ao silêncio, por certo, a proteção, constitucionalmente assegurada, contra a auto-incriminação, de sorte a não se poder concluir desfavoravelmente ao indiciado, ou acusado, pelo simples fato de ter-se calado, isto é, de abster-se de prestar declarações, em especial das que possam incriminá-lo. 20

A assistência de advogado, por sua vez, não há de ser concebida como assistência passiva, de mero espectador dos atos praticados pela

18. Curitiba, Juruá, 1989.

19. Porto Alegre, Lejur, 1991.

20. V., a respeito, Daniele Saint-Laurent, ob. cit., p. 124-5. 
autoridade policial e seus agentes, mas, sim, assistência técnica, na acepção jurídica do termo, qual seja a de atuação profissional de advogado.

Por via de conseqüência, essa atuação só poderá atender ao desígnio do legislador constituinte se for efetiva, balizada na contraditoriedade indispositiva, ínsita ao processo penal na integralidade da persecutio criminis, com o exercício da defesa técnica, na sua maior amplitude, tal como preconizado no transcrito inc. $L V$.

Poder-se-á dizer, a propósito, que este se refere a processo, e não a procedimento, como é o inquérito policial; nem a indiciado, ou seja, a quem, si et in quantum, face à convergência de dados indicadores, atribuída a autoria de infração penal. ${ }^{21} \mathrm{E}$, por esse motivo, não poderia ter a larga aplicação aqui e agora alvitrada.

Deve ser verificado, todavia, que a confusão terminológica, e até mesmo conceptual, entre processo e procedimento se tradicionalizou em nosso País. Fala-se num, quando, na realidade, se cogita do outro, e chega-se ao ponto de, no texto de uma Constituição Federal, expressar "processo administrativo", quando se está querendo aludir a procedimento administrativo.

Ora, assim sendo, se o próprio legislador nacional entende ser possível a utilização do vocábulo processo para designar procedimento, nele se encarta, à evidência, a noção de qualquer procedimento administrativo e, conseqüentemente, a de "procedimento administrativo-persecutório de instrução provisória, destinado a preparar a ação penal", que é o inquérito policial. ${ }^{22}$

Por outro lado, quando se menciona "acusados em geral", na examinada preceituação constitucional, certamente se pretende dar a mais larga extensão às palavras, com referência óbvia a qualquer espécie de acusação, inclusive a ainda não formalmente concretizada. Assim não fosse, afigurar-se-ia de todo desnecessária a adição "em geral"; bastaria a alusão a "acusados".

21. V., a propósito, nosso estudo Indiciamento e qualificaçāo indireta, Revista dos Tribunais, Sāo Paulo, n. 571, p. 292 e ss., 1983.

22. Cf. José Frederico Marques, ob. cit., v. 1, p. 153. 
Não há como aceitar-se, com a devida vênia, o argumento contrário daqueles que, como Celso Ribeiro Bastos, ${ }^{23}$ entendem que não se pode falar em "acusados" no inquérito policial, por tratar-se de "um meio de apuração", não havendo, ainda, "uma irrogação a alguém da prática de um ato condenável, no caso um ilícito penal"

$\mathrm{E}$ isso, tanto mais quanto se tenha presente anterior lembrança do mesmo e ilustre autor, ${ }^{24}$ de impor-se "reconhecer que o dispositivo procurou ser de extrema abrangência", no que diz respeito "aos destinatários"; ao ponto de pregar sua inteira valia, e aduzindo, verbis: "Com efeito, além de tornar certo que o preceptivo se volta aos litigantes em processo judicial, conferiu igual destinação aos envolvidos em processos administrativos. Esta inclusão foi extremamente oportuna porque veio consagrar uma tendência que já se materializava em nosso direito, qual seja: a de não despertar estas garantias aos indiciados em processos administrativos. Embora saibamos que as decisões proferidas no âmbito administrativo não se revestem do caráter de coisa julgada, sendo passíveis portanto de uma revisão pelo Poder Judiciário, não é menos certo, por outro lado, que já dentro da instância administrativa podem perpetrarse graves lesões a direitos individuais cuja reparação é muitas vezes de difícil operacionalização perante o Judiciário. Daí porque esta preocupação em proteger o acusado no curso do próprio processo administrativo ser muito vantajosa, mesmo porque, quanto melhor for a decisão nele alcançada, menores são as chances de uma renovação da questão diante do Judiciário" (com grifos nossos).

Realmente, referendada a extensão dos direitos indicados no dispositivo constitucional aos "indiciados em processos administrativos", e sendo inequívoco, outrossim, como visto, que o inquérito policial é uma das modalidades de procedimento administrativo, não há como negar sua abrangência pelo novel regramento da Carta Magna da República.

23. Comentários à Constituição do Brasil (em co-autoria com Ives Gandra Martins), São Paulo, Saraiva, 1989, v. 2, p. 268.

24. Ibidem. 
Como bem intuiu Nagib Slaibi Filho, 25 "assistência de advogado não significa simplesmente a presença fiscalizadora do profissional habilitado aos atos processuais, mas, sim, sua interveniência no processo, pois senão não seria a advocacia essencial à função jurisdicional. Ainda no inquérito policial ou no auto de prisão em flagrante delito, tem o advogado poder de reperguntar, requerer diligências e providências que achar convenientes ao ato, sem prejuízo, é claro, da autoridade processante deferir, ou indeferir, sempre com fundamentação, o que lhe foi requerido". E concedida, induvidosamente - permitimo-nos acrescentar - ao defensor técnico do indiciado a utilização dos meios em lei previstos para impugnar qualquer ato arbitrário da autoridade policial.

O mais que se pode admitir, na exegese do preceito constitucional focado, é a dispositividade da determinação da atuação de defensor do indiciado (que não pode ser confundida, à evidência, com a contraditoriedade real, ínsita à sua efetiva assistência) no transcorrer da informatio delicti. ${ }^{26}$

Em verdade, o fato de a Constituição Federal conferir ao cidadão envolvido na persecutio criminis, desde o seu início, o direito à assistência de advogado não significa, obviamente, que ele esteja obrigado a ser assistido pelo causídico.

Além do que, nesse ponto, ela mais não fez do que consagrar habilidosa prática de profissionais experimentados que, com largo descortino jurídico e acuidade, sempre têm prestado efetiva assistência ao indiciado no desenvolvimento do inquérito policial. Às vezes, com alguns percalços, certamente; porém, via de regra, com resultados amplamente satisfatórios.

Já agora, consubstanciada a atuação espontânea do defensor num direito subjetivo do seu constituinte, a atividade defensiva prévia ganha bem maior dimensão, ao ponto de propiciar, sem qualquer sofisma, a contraditoriedade no inquérito policial.

25. Ob. cit., p. 318.

26. V, a respeito, Vicente Gimeno Sendra, ob. cit., p. 98, verbis: "La intenvención del defensor en el proceso penal venía, pues, jalonada por tres estadios procesales: la defensa técnica prohibida (antes del procesamiento), la defensa permitida (a partir del procesamiento) y la defensa técnica obligatoria que habia de suceder con el trámite de calificación provisional". 
Diz essa afirmação, de resto, com a inafastabilidade da perquirição da verdade material em todo o desenrolar da persecutio criminis, como dado mais relevante do fundamento do processo penal, qual seja, a liberdade jurídica do perseguido: a par da imprescindibilidade de adequada assistência técnica ao indiciado que, desde logo, a deseja, presenta-se, também inarredável, "la necesidad de determinar la verdad en sustancia por encima de los excesos rituales, a fin de posibilitar el debido control de la justicia sobre los organos administrativos"..27

E representa, também, uma autêntica conquista do Direito Processual Penal Constitucional moderno, como clarifica José I. Cafferata Nores $^{28}$ ao publicizar sua colaboração à Convenção Constituinte e subseqüentes reflexões formuladas em curso específico ministrado no "Centro de Estudios de Derecho Procesal Dr. Alfredo Vélez Mariconde", verbis: "En ese sentido, el texto propuesto puntualiza que 'es inviolable la defensa en juicio de la persona u de los derechos', y agrega que 'todo imputado tiene derecho a la defensa técnica, aun a cargo del Estado, desde el primer momento de la persecución penal' Entendemos que es necesario dejar plasmado en la Constitución Provincial el derecho del imputado a contar con el consejo y la asistencia de un abogado durante todo el curso del procedimiento penal, incluída la etapa prevencional a cargo de la Policía".

Trata-se, enfim, de um direito fundamental, que, por ser "um elemento decisivo do processo penal", não pode ser transformado, em nenhuma hipótese, em "mero requisito formal";29 e cuja observância, por isso, se impõe, sob pena de nulidade dos atos procedimentais praticados sem a efetiva assistência do defensor constituído pelo indiciado, ou público (cf., também, arts. 5, LXXIV, e 134 da Constituição Federal).

7. Imprescindibilidade de autorização judicial para a busca e apreensão

Faz por merecer, igualmente, nossa especial atenção, no trato da matéria versada, a busca e apreensão.

27. Cf. Alejandro D. Carrió, ob. cit., p. 101.

28. Eficacia...ob. cit., p. 29-30.

29. Cf., a respeito, José Antonio Tome Garcia, ob. cit., p. 112. 
Várias das disposições do vigente Código de Processo Penal, que lhe são específicas, encontram-se superadas pela Constituição Federal de 1988, dada a preceituação contida no inc. XI do art. $5^{\circ}$, assim redigido: "a casa é asilo inviolável do indivíduo, ninguém nela podendo penetrar sem consentimento do morador, salvo em caso de flagrante delito ou desastre, ou para prestar socorro, ou, durante o dia, por determinação judicial".

Como se tem da sua parte final, em situações normais (isto é, não sendo caso de prisão em flagrante, de desastre, ou de prestação de socorro) imprescindível é a determinação judicial para que algo se busque, com a finalidade da respectiva apreensão. ${ }^{30}$

Por via de conseqüência, a autoridade policial e/ou seus agentes não mais poderão realizá-la, sem que, prévia e justificadamente, pleiteada e obtida a correspondente ordem de órgão jurisdicional competente.

Esta, todavia, poderá ser genérica, isto é, sem especificação do que deva ser buscado e apreendido, até porque muitas vezes impossível a definição do objeto da busca e apreensão.

Deve ter-se presente, nesse caso, que a nossa Carta Magna, diferentemente da Emenda n. IV da Constituição dos Estados Unidos da América, na qual a respectiva ordenação "deve determinar com precisão o lugar e os objetos sobre os quais versará o procedimento deste tipo", ${ }^{31}$ não estabeleceu a necessidade dessa especificação, de sorte a firmar a crença de que se faz suficiente a determinação judicial inespecífica.

Só mesmo quando não efetuar pessoalmente a diligência, é que a autoridade policial, lastreada na ordem judicial, deverá expedir mandado específico, visando ao seu cumprimento com total exação; vale dizer, sem qualquer espécie de abuso.

30. V., acerca de busca e apreensāo, Sérgio Marcos de Moraes Pitombo, Do seqüestro no processo penal brasileiro, São Paulo, J. Bushatsky, 1973, p. 59 e ss.; e nosso Do corpo de delito no direito processual penal brasileiro, Sāo Paulo, Saraiva, 1978, p. 249 e ss., conceituando a busca como "a procura ou perquisição de coisa ou pessoa determinada ou determinável"; e a apreensão como a "tomada de coisa ou retenção de pessoa, uma e outra determinada, de qualquer modo relacionadas com o fato criminoso investigado", representando, portanto, o resultado profícuo da busca.

31. Cf. Alejandro D. Carrió, ob. cit., p. 58. 
Foi esse, certamente, e a exemplo do que acontece também alhures, ${ }^{32}$ o escopo que animou o nosso legislador constituinte, procurando "precaver tanto quanto possível a repetição de medidas tão odiosas e violentas", com a estatuição de regramento de meridiana clareza para a realização de busca e apreensão em domicílios ou em locais a ele equiparados. ${ }^{33}$

$\mathrm{E}$, por isso, como exposto, distinguem-se, à luz da preceituação constitucional analisada, a determinação judicial sempre necessária e, até, inespecífica e o mandado de busca e apreensão, a ser expedido, se for o caso (cf. art. 241 do Diploma legal por último indicado), pela autoridade policial, e com a também imprescindível especificação da coisa ou pessoa buscada.

8. Interceptação de comunicações telefônicas

Concluindo este breve estudo, não podemos deixar de examinar, ainda, o teor do inc. XII do art. $5^{9}$ da Constituição Federal, segundo o qual "é inviolável o sigilo da correspondência e das comunicações telegráficas, de dados e das comunicações telefônicas, salvo, no último caso, por ordem judicial, nas hipóteses e na forma que a lei estabelecer para fins de investigação criminal ou instrução processual penal".

Resultou essa preceituação, especialmente na parte final, de sugestão encaminhada, à Assembléia Nacional Constituinte, pelo Conselho Nacional de Política Criminal e Penitenciária, a partir de parecer por nós elaborado acerca da violação do disposto no $\S 9^{9}$ do art. 153 da Emenda Constitucional n. 1, de 17 de outubro de 1969, em presídios, verberando o estabelecimento, pela legislação ordinária, de restrição ao direito subjetivo do preso, condenado ou não, de comunicação com o mundo exterior, dada a sua manifesta inconstitucionalidade.

Entendeu-se, então, que a situação deveria modificar-se no tocante à comunicação telefônica, passível de interceptação sempre que imprescindível à apuração da verdade material, numa persecução penal em curso.

32. V. José I. Cafferata Nores, Eficacia...ob. cit., p. 62.

33. Cf. art. 246 do Código de Processo Penal; e, nesse idêntico senso, Celso Ribeiro Bastos, ob. cit., v. 2, p. 68 . 
A novel idéia, como não podia deixar de ser (até porque consagrada, moderna e universalmente, como um dos mais eficientes meios de prova em matéria penal), vingou, de sorte a permitir-se, já agora, a explicitada interceptação, mediante a concorrência dos seguintes requisitos:

a) previsão em lei ordinária (ainda inexistente);

b) autorização, exclusivamente, por órgão jurisdicional competente; $\mathrm{e}$,

c) destinação especificada à constituição de prova em investigação criminal ou em instrução processual penal.

Diz de perto, ademais, com dois outros preceitos de nossa Carta Magna, quais sejam os incs. LV e LVI do art. $5^{\circ}$, o primeiro determinante do contraditório e da ampla defesa, e o outro assim redigido, verbis: "são inadmissíveis, no processo, as provas obtidas por meios ilícitos".

Com efeito, a garantia da ampla defesa, seja qual for a natureza do processo, compreende: a) o direito do interessado de ser informado; b) a bilateralidade da audiência (contraditoriedade); e c) o direito à prova legitimamente obtida ou produzida.

Abstração feita do direito à informação sobre a existência de persecução penal, que não se coaduna com o ponto focado, bem é de ver que não afronta a regra do contraditório procedimento que comporta decisão inaudita altera pars, dado ostentar ela caráter de provisoriedade, ensejando-se, sempre, ao outro sujeito parcial do processo (inclusive, como é óbvio, ao imputado), antes que seja definitivamente considerada, a possibilidade de ampla defesa. ${ }^{34}$

Em verdade, nessas hipóteses de "contraddittorio posticipato", a garantia da audiência bilateral não se delineia violada, mas, por certo, tão-só dilargada para um momento sucessivo à ordem e realização da providência liminar, "che poi a sua volta, allorche si realizza, e assistita da tutte le garanzie del modello ordinario". 35

34. V., a propósito, Giuseppe Martinetto, Contradittorio (principio del), verbete, in Novissimo digesto italiano, 1959, v. 4, p. 461.

35. Cf. Vittorio Colesanti, Principio del contradittorio e procedimenti special, Rivista di diritto processuale, n. 4, p. 588 e 618, 1975. 
Ademais, em matéria penal, inexiste um processo cautelar, como tal considerado, podendo as medidas assecuratórias, preventivas ou incidentes, ser tomadas em qualquer tempo, a fim também de que os fatos restem devidamente esclarecidos através de prova legitimamente obtida ou produzida.

A Constituição Federal veda, como visto, a consecução desta por meios ilícitos, impondo-se ressaltar a imprestabilidade da prova viciada pela ilegalidade consubstanciada em sua realização, ou com ofensa a direito constitucionalmente assegurado ao cidadão envolvido numa persecução penal. ${ }^{36}$

Como explica José Antonio Tome Garcia, ${ }^{37} \mathrm{em}$ doutrinação que bem se ajusta ao nosso ordenamento jurídico, "constatada la inadmissibilidad de las pruebas obtenidas con violación de los derechos fundamentales, su recepción procesal implica una ignorância de las garantías propias del proceso (art. 24-2Q $\mathrm{CE}$ ), implicando también una inaceptable confirmación institucional de la desigualdad entre las partes en el juicio, desigualdad que se ha procurado antijurídicamente en su provecho quien ha recabado los instrumentos probatorios en desprecio de los derechos fundamentales de otro.'

Em suma, não podendo surtir qualquer efeito processual, no processo penal, prova obtida ou produzida com violação, direta ou indireta, de direito tido como fundamental, especialmente o de liberdade, deve ter-se presente a admissibilidade, apenas, e concorrentes os requisitos supraenunciados, da interceptação (não da escuta, que, com ela, não pode ser confundida) telefônica nas situações em que, justificada pela autoridade policial a sua necessidade, obtenha a indispensável ordem judicial, a ser rigorosamente observada, isto é, sem qualquer alargamento ou extensão.

E a respectiva fita, após periciada, e copiada datilograficamente, deverá ser lacrada e remetida a Juízo com os autos da investigação criminal efetuada.

São essas cautelas mínimas, que não poderão ser ignoradas pelo

36. V., também, Celso Ribeiro Bastos, ob. cit., v. 2, p. 272-6; José I. Cafferata Nores, Eficacia...ob. cit., p. 90-1.

37. Ob. cit., p. 126. 
legislador ordinário, ao regulamentar a preceituação constitucional analisada, e cuja inobservância poderá inutilizar a importante prova conseguida pelo interceptador. 